\title{
Democracia no feminino: o silenciamento histórico de jornalistas mulheres opositoras da ditadura militar brasileira, em análise do caso Míriam Leitão ${ }^{1}$
}

Manoela Caldas

Pontifícia Universidade Católica do Rio de Janeiro - PUC-Rio

Departamento de Comunicação Social - Bacharelado em Jornalismo

\section{RESUMO}

Esta pesquisa centra-se no silenciamento histórico da atuação de jornalistas mulheres opositoras da ditadura militar brasileira, com estudo de caso de Míriam Leitão. Analisase a experiência da jornalista Míriam Leitão como profissional e ex-presa política. Jamais para tê-la como uma vivência especial ou isolada, mas como um microcosmo da interseção de jornalismo, oposição à ditadura e feminismo que motivou esta pesquisa. O objetivo é explorar as complexidades político-sociais existentes nas redações, nos partidos clandestinos, no poder militar e no próprio feminino dos anos 1960 e 70 no Brasil para, assim, entender os motivos que resultaram nas memórias majoritariamente masculinas construídas sobre a época. Para tal, foram utilizadas bibliografias específicas sobre a jornalista, o regime, a imprensa e movimentos de mulheres, além de uma entrevista presencial com Míriam Leitão.

\section{PALAVRAS-CHAVE}

Jornalismo; Feminismo; Ditadura; Brasil; Míriam Leitão.

\section{Introdução}

O Brasil viveu entre 1964 a 1985 sob o comando de uma ditadura civil-militar, cujas feridas permanecem abertas na dinâmica social e política do país. O golpe foi tramado interna e externamente, sob o contexto da Guerra Fria, que dividiu o mundo entre comunismo e capitalismo. O historiador Marco Napolitano divide os 21 anos do regime militar brasileiro em três fases: a legitimação legista, de 1964 até 1968; os anos de chumbo, de 1969 a 1978; e a reabertura política, de 1979 a 1985. Os Atos Institucionais eram essenciais para manter o ar de legalidade da ditadura e afirmar o caráter tutelar do Estado, despersonalizando o poder político. Ao todo, foram 17 AI-s e 104 atos complementares. Era uma forma de rotinizar o poder; a busca por legitimação implementou um novo modelo ditatorial para países latino-americanos.

\footnotetext{
${ }^{1}$ Artigo derivado de monografia de graduação em Jornalismo, orientada pela professora Itala Maduell Vieira e apresentada em dezembro de 2019.
} 
Entre 1967 e 1968, a oposição à ditadura se mobilizou, principalmente pelo protagonismo do movimento estudantil, que conseguiu alcançar alguns setores da classe média. O episódio em que a Polícia Militar matou o estudante Edson Luís durante uma manifestação no Rio de Janeiro foi o estopim para o levante da voz popular, e por consequência, para a intensificação da mão de ferro. A violência policial contra manifestantes chegou ao ápice em 21 de junho de 1968, dia conhecido como "sextafeira sangrenta", pela morte de quatro pessoas e dezenas de feridos. Em resposta à chacina, organizou-se a Passeata dos Cem Mil, o maior protesto daquele período. No mês seguinte, manifestações de rua foram proibidas. Como resposta, parte da esquerda passou a se organizar como guerrilha armada. Além da preocupação com as ruas, o presidente também perdeu o controle do sistema político, com a Câmara e Congresso contra ele.

O ano de 1968 é conhecido como aquele que não terminou. O Ato Institucional no 5 foi instaurado em 13 de dezembro, após os militares negarem a proposta civil de um estado de sítio constitucional. Com o general Emílio Médici na Presidência, os anos de chumbo foram marcados pela transformação do estado autoritário em um estado policial violento. Se antes a perseguição era prática exclusiva para líderes populares de esquerda, com o AI-5 qualquer cidadão com um posicionamento contrário ao regime poderia conhecer a repressão (NAPOLITANO, 2018, p.86-95).

Na fase mais cruel da ditadura militar brasileira, o presidente tinha poder absoluto. $\mathrm{O}$ Congresso Nacional foi fechado e foi decretada uma versão ainda mais radical da Lei de Segurança Nacional, com o objetivo de exterminar guerrilheiros (NAPOLITANO, 2018, p.119-126). A nova legislação previa pena de morte por fuzilamento, prisão perpétua e autorizava a prisão de qualquer cidadão por dez dias, em regime de incomunicabilidade.

O regime militar sempre agiu com violência, mas naquele momento montou-se uma máquina de repressão burocratizada que combinava facetas legais e ilegais. Praticamente todos os direitos individuais foram suspensos. Se antes ainda havia certo espaço para a oposição, com o AI-5 "o martelo de pilão da repressão não matou apenas moscas, mas tudo que ousasse voar" (NAPOLITANO, 2018, p.128).

A burocratização da mão de ferro se materializou com a institucionalização da tortura, que superou qualquer limite jurídico ou humanitário e feria até mesmo a ética militar, que determina o tratamento digno de prisioneiros. Muitas equipes de torturadores 
tinham centros clandestinos, onde atuavam de forma autônoma. A tortura não tinha como objetivo apenas extrair informações, mas humilhar o "inimigo" e reduzir sua moral. Outro método adotado foi o desaparecimento de corpos, que substituiu a prática anterior de forjar a morte de assassinados pela tortura. Além do desaparecimento físico do corpo, os militares sepultavam os mortos com nomes trocados e organizavam um aparato de contra-informação, alimentando pistas falsas para dispersar os esforços de busca dos familiares (NAPOLITANO, 2018, p.135-140).

Os militares nunca assumiram seus mecanismos de repressão. No processo de abertura política do general João Baptista Figueiredo, foram formados núcleos por todo o país para denunciar e cobrar justiça pela violação de direitos humanos. A lei no 6.683, conhecida como a Lei da Anistia, aprovada em 28 de agosto de 1979, garantiu a anistia de 200 presos políticos. Mas foi considerada um golpe dentro do golpe por ex-presos políticos e familiares de opositores mortos e desaparecidos: a lei não contemplou os condenados por práticas descritas como terrorismo, assalto, sequestro e atentado pessoal e, principalmente, a anistia também foi aplicada aos agentes de Estado, o que garantiu o perdão de policiais e militares que praticaram torturas, prisões ilegais e outros crimes que violam os direitos humanos contra os militantes.

Ainda hoje, em Estado democrático, a ineficiência da lei de 1979 é um dos desafios mais complexos no ofício de manter viva a memória dos horrores da ditadura. $\mathrm{O}$ Ministério Público Federal brasileiro apresentou dezenas de denúncias contra militares acusados de tortura, execução e ocultação de cadáveres durante a ditadura militar, mas nenhum dos envolvidos foi preso porque o dispositivo legal impede a punição dos acusados (CHARLEAUX, 2015).

Em 2016, ao votar pelo impeachment da presidente Dilma Rousseff, ex-presa política da ditadura, o então deputado federal e ex-capitão do Exército Jair Bolsonaro homenageou o coronel Carlos Alberto Brilhante Ustra, torturador de Dilma. Em 2018, Bolsonaro foi eleito presidente, enquanto no Chile um coronel foi destituído por saudar um militar condenado por 71 crimes na ditadura de Pinochet (MONTES, 2018). E 2019 terminou com o presidente da República, seu filho deputado e seu ministro da Economia ameaçarem a oposição com uma "reedição do AI-5".

A impunidade se reflete na memória. $E$, na era da pós-verdade, preservar memórias torna-se urgente. A ditadura militar brasileira foi bem-sucedida em criar uma narrativa para legitimar a supressão da democracia, assim como para alimentar distorções e 
dúvidas sobre o que realmente aconteceu no país durante os 21 anos de repressão. Destacamos o desaparecimento de corpos de militantes, a censura à imprensa e a impunidade garantida pela Lei da Anistia como fatores essenciais para tornar incompleto o ciclo da memória.

Com a redemocratização, o trabalho de pesquisadores e jornalistas possibilitou que as lacunas dessa história fossem preenchidas e amplamente debatidas, trazendo à tona fatos até então desconhecidos pela maioria. Mas, no conjunto, o que se observa ainda é um relato majoritariamente masculino. Interessa agora enriquecer esta história incorporando óticas suprimidas, mais especificamente a das mulheres.

A pesquisa foi realizada a partir de revisão bibliográfica sobre a imprensa no período e sobre a atuação da jornalista Míriam Leitão, uma das mais bem-sucedidas e premiadas jornalistas brasileiras, particularmente o livro Em nome dos pais (2017), escrito por seu filho Matheus Leitão, e o documentário produzido pela Outros Olhos Filmes para a $14^{\circ}$ Congresso da Associação Brasileira de Jornalismo Investigativo (Abraji), em 2019. Foi realizada entrevista semiestruturada com a jornalista no Rio de Janeiro.

\section{A relação entre imprensa e Estado no Brasil}

Anne-Marie Smith e Beatriz Kushnir fazem uma densa análise das formas de repressão do regime à grande imprensa, da forma como o autoritarismo foi recebido nas redações e também da relação histórica entre Estado e imprensa no Brasil. Smith (1997) defende que os grandes veículos brasileiros sempre tiveram forte relação com o Estado, e questiona se houve plena liberdade de imprensa em algum momento da história do país: "Se o Estado busca a imprensa para controlar a sociedade, a imprensa também tem capacidade de influenciar governos" (SMITH, 1997, p.17-21). A carência de mecanismos democráticos e transparentes moldou a postura da imprensa para o cenário dos anos 1960. Os principais jornais brasileiros não apenas defenderam o golpe de 1964, mas trabalharam diretamente na construção do apoio da população ao governo militar, ao fomentar a histeria anticomunista com posicionamento firme contra o presidente João Goulart (CARVALHO, 2010, p.55).

A imprensa foi uma ferramenta fundamental para o estabelecimento e manutenção da ordem. "O Ministério da Justiça havia criado o Serviço de Informação do Gabinete (Sigab), onde agiam às escondidas os censores políticos, atentos vigilantes do conteúdo 
das notícias que milhões de brasileiros podiam ou não tomar conhecimento" (MARCONI, 1980, p.56). Diferente do DIP (Departamento de Imprensa e Propaganda, responsável pela censura no Estado Novo) em muitos aspectos e principalmente porque foi legalizado por decreto, o Sigab esteve fora de qualquer organograma, tanto do Ministério da Justiça como do DPF - era um órgão entre o ministro da Justiça e o diretor da Polícia Federal, que não foi instituído formalmente. "Ao Sigab cabia o telefonema diário às redações de todo o país em que se informava o que era proibido publicar, assim como a visita aos jornais sob censura prévia para checar o cumprimento das ordens" (KUSHNIR, 2004, p.123).

Ela [a censura] se destina a servir aos interesses dos que se encontram no poder ao gerar ignorância e distorção, ao enfraquecer ou incapacitar um povo submisso. [...] Sob a censura, manipulam-se a compreensão da realidade social e natural, a posição de alguém no mundo, principalmente, com frequência, dos que detêm o poder. (SMITH, 1997, p.136)

Ao analisar a história do país, entende-se que não foi inédito ou surpreendente que a ditadura militar tenha restringido a liberdade de imprensa. Para Smith, o fato de a imprensa brasileira nunca ter vivido tempos de plena independência significa que também não havia uma cultura de mobilização para garantia deste direito. A resistência ainda teria de ser criada. "A liberdade de imprensa não podia ser reclamada com base numa herança reconhecida e compartilhada" (SMITH, 1997, p.30).

A autora destaca quatro pontos para entender a atuação da imprensa na ditadura: a transformação do Judiciário, a institucionalização e burocratização do aparelho repressor e dos métodos de tortura, as divisões internas dos militares entre "moderados" e "linha dura" e a busca pela legitimidade política do regime. Ao mesmo tempo que estes aspectos dificultavam a atuação dos jornalistas, havia interesse da ditadura de se disfarçar de democracia. A preocupação dos militares por burocratizar até as práticas mais cruéis reflete tal tentativa de legitimação. E, como a liberdade de imprensa é um dos pilares máximos de regimes democráticos, a farsa dos militares ajudava os jornais brasileiros a firmarem seu espaço.

Mesmo a parcela da população civil que apoiou o golpe discordava da repressão. E em pleno fervor do milagre econômico, argumento que sustentava a ditadura para a classe média e elite, os militares precisavam da imprensa para proclamar suas conquistas. Como de costume, a imprensa era vista como um potencial aliado e um ameaça ao mesmo tempo (SMITH, 1997, p.36-47). 


\section{A censura aos veículos de comunicação na ditadura militar brasileira}

Especialmente entre 1968 e 78, a censura à imprensa no Brasil assumiu diversas formas - todas ilegais, disfarçadas e negadas. A população não apenas tinha negado o acesso à informação, como sequer sabia que as poucas notícias a que tinham acesso eram brutalmente restringidas ou alteradas (SMITH, 1997, p.135-166). Apesar de a censura prévia ser a mais disseminada na memória sobre o período, este era apenas um dos métodos utilizados. A autocensura era mais frequente. Muitos jornalistas nem se davam ao trabalho de escrever notícias que sabiam que não seriam publicadas.

Chegavam às redações recados de assuntos proibidos. Havia um sistema de distribuição com normas estritas e padrão de circulação dentro de cada veículo. A censura era rotineira, banalizada, e impessoal, sem agentes responsáveis aparentes (SMITH, 1997, p.169-198). A censura prévia foi menos frequente, mas teve grande importância simbólica e financeira. Agentes do Estado analisavam o conteúdo dos veículos antes de serem impressos ou vendidos. Havia perda de tempo, de recursos materiais e de verba.

A censura prévia transformou o jornalismo em estratégia. O principal alvo da censura prévia não era a grande mídia, e sim a chamada imprensa alternativa, desvinculada das políticas dominantes (KUCINSKI, 1991, p.XIII). Esses veículos representavam o desejo das gerações dos anos 1960 e 70 de protagonizar uma transformação social. Tinham natureza política, não mercantil. Diferente da grande mídia, denunciaram violações de direitos humanos desde o início do regime e criticaram a ditadura até nos anos de milagre econômico. A imprensa alternativa esteve entre os principais alvos da linha dura, assim como os jornalistas que compunham as equipes.

Seria injusto e incorreto afirmar que a imprensa brasileira não resistiu à censura, assim como é idealizada a imagem de "imprensa heróica". Se os militares se mantiveram no poder durante 21 anos é porque existiu um amplo apoio civil. A versão que dá a entender que a oposição era unânime colabora com o apagamento de quem se expôs ao risco de defender a democracia em uma ditadura. Como mostra Kushnir, existiram jornalistas opositores e colaboracionistas. Assim como se deve lembrar que veículos de comunicação tradicionais também são empresas privadas, e para acompanhar o mercado, muitas vezes abrem mão de ser canais de reflexão de conflitos sociais. "Assim como nem todas as redações eram de esquerda, nem todos os jornalistas fizeram do ofício um ato de resistência ao arbítrio" (KUSHNIR, 2004, p.26). 
Em seu livro, Kushnir foca na intersecção entre jornalistas e censores. Caracterizou jornalistas que trocaram as redações pela burocracia e os policiais que atuaram como jornalistas como "cães de guarda", uma vez que não determinaram as regras da censura, mas eram peças-chave para a garantia do modus operandi da ditadura (2004, p.28).

Muitos dos jornalistas selecionados [para a pesquisa da autora] tinham também uma atividade profissional ligada à Secretaria da Segurança Pública, e alguns dos censores, por outro lado, haviam sido jornalistas ou o jornalismo era a única atividade que podiam exercer concomitantemente com a função de técnico da Censura. Além desse traço, ao prestarem os concursos do DPF, tornavam-se policiais e passavam a exercer uma atividade camuflada com a chancela de intelectual (KUSHNIR, 2004, p.36).

Já Smith (1997) elabora a inércia, que segundo ela, foi o comportamento dominante dos jornalistas nas redações frente à censura. Para a autora, houve tentativas de desafiar e rejeitar a autocensura, mas a grande parte dos atores da imprensa havia se acomodado, tornado-se inerte. O jornalista Denis de Moraes, então de O Globo, ao ser questionado sobre a postura passiva dos jornalistas diante os bilhetinhos, respondeu:

\begin{abstract}
As regras, os limites de autoridade eram tão nítidos que você sentia intimidado de desafiá-los, de perguntar. Você ficava no seu canto. Os limites eram tão claros que não adiantava nada forçar. O que aconteceria com você? Demissão. [...] Como jornalista, você entregava seu material, e aí terminava suas responsabilidades. A lei implícita era: não faça perguntas (SMITH, 1997, p.146).
\end{abstract}

Smith encerra o livro com entrevistas que exploram as preocupações e perdões da imprensa, assim como as justificativas e as alegações dos representantes do Estado. A autora entrevistou jornalistas da grande imprensa e da alternativa, congressistas, policiais que aplicavam a censura e autoridades da Polícia Federal que os comandavam (1997, p. 169-198). Destacamos a entrevista com Moacyr Coelho (1997), então chefe da Polícia Federal. Segundo ele, a situação era de uma guerra suja, que precisava ser travada com meios sujos. Coelho não justifica as medidas ilegais contra a imprensa, mas explica que era uma consequência compatível com os tempos extremos. O exchefe da PF discorda que a censura era aceita pela imprensa. Ao contrário, queixou-se dos esforços da imprensa para burlar o controle policial, deixando evidente que não havia cooperação total dos jornalistas (COELHO em SMITH, 1997, p.190-197). Ainda na entrevista a Smith, Coelho explica a censura como um "acordo de cavalheiros". Não satisfeito com as palavras escolhidas, somou-as à expressão "acordo forçado". Repetiu as três palavras algumas vezes ao longo da entrevista, pois segundo ele, elas captam a natureza da autocensura: "Foi um acordo forçado. Um acordo forçado. Foi um acordo 
muito civilizado, mas forçado. Não vivi como eu gostaria de ter vivido, mas para sobreviver tive de fazê-lo" (COELHO em SMITH, 1997, p.198).

Após as entrevistas, Smith (1997) analisa as três justificativas dos jornalistas - apoio, medo e rotina -, que explicariam a postura inerte da imprensa em relação à censura. A autora enfatiza que mesmo os que apoiavam o regime não endossaram a repressão, anulando o primeiro argumento. Já o medo existia, mas não era paralisador; não havia uma cultura do medo forte o suficiente.

Para a autora, portanto, a rotina foi o principal elemento responsável pela inércia que dominava as redações. O sistema rotineiro e burocrático fez com que a imprensa brasileira praticasse modalidades diárias de inércia, em um processo de normatização da repressão. Entrevistada para esta pesquisa, a jornalista Míriam Leitão refuta o argumento de inércia apontado por Smith e defende que a imprensa fez um trabalho que considera "brilhante" para resistir ao autoritarismo. Afirma que aquela geração de jornalistas aprendeu a trabalhar com a palavra, que a escolha do termo precisava ser sutil para não alarmar a censura, mas certeira o suficiente para passar o real peso da notícia para além do que os militares queriam que fosse dito. Ainda que os jornalistas pessoalmente discordassem deste controle, a imprensa nunca conseguiu se opor abertamente, pelo menos não à altura da gravidade da situação (SMITH, 1997, p.199214).

Na contramão das ditaduras sul-americanas, as décadas de 1960 e 70 foram marcadas pela ascensão dos movimentos sociais e, não por acaso, como a época em que as mulheres começaram a se emancipar ao entrar nas universidades e no mercado de trabalho. Como o nível de escolaridade de mulheres tornou-se superior ao dos homens, a obrigatoriedade do diploma jornalístico implementada pela Lei da Imprensa da ditadura fomentou a presença feminina nas redações (ABREU e ROCHA, 2006, p.9). A natureza social do jornalismo foi um dos principais motivos para estudantes mulheres optarem pelo curso naquela época. O desejo de participação política junto com o gosto pela escrita fez do jornalismo uma ferramenta para que estas jovens tivessem voz em meio à repressão de gênero e da ditadura. Mas a presença feminina nas redações dos anos 60 era quase exclusivamente nas editorias de maternidade, moda, culinária e outros assuntos do que então era considerado interesse do público feminino.

Até então, a cobertura de política e economia ficava a cargo de jornalistas homens. Este cenário só mudou a partir do momento em que as esferas sociais foram 
transformadas e com isso, mulheres também passaram a ser leitoras e repórteres de hard news. O jornalismo se torna uma profissão cada vez mais feminina, mas, apesar de estarem presentes nas redações, as mulheres raramente ocupam cargos acima da gerência média. Ainda hoje, faltam estudos que analisem o papel das mulheres jornalistas nos espaços antes ocupados majoritariamente por homens (ABREU e ROCHA, 2006, p.7-11).

Antes de analisar o recorte de gênero, é preciso entender, assim como na imprensa, o peso das mulheres brasileiras no apoio ao regime. Tal qual a intersecção proposta de jornalistas mulheres opositoras, os caminhos de mulheres e veículos pró-regime também se cruzam, como registra a pesquisadora Janaina Martins Cordeiro (2009).

A Campanha da Mulher pela Democracia (Camde) tinha como principal bandeira a luta contra o comunismo e o governo Goulart. Apresentando-se como mães e falando em nome da mulher brasileira, seus clamores mobilizavam sentimentos e apelavam a tradições que não se restringiam às elites: o medo de que o comunismo destruísse a família, a pátria e a Igreja era real e partilhado pelos mais diversos setores da população (CORDEIRO, 2009, p.51). O lançamento oficial da Camde, em 1962, ocorreu no auditório do jornal $O$ Globo, a convite do diretor Rogério Marinho, irmão de Roberto. O evento resultou em uma manchete na primeira página, com o título $A$ mulher brasileira está nas trincheiras. O veículo atuou como porta-voz do movimento no Rio de Janeiro, assim como o Estado de S. Paulo fez com a União Cívica Feminina em São Paulo:

\begin{abstract}
A estreiteza das relações entre os grupos femininos e os jornais da grande imprensa ajuda-nos a situar socialmente os grupos femininos, ou pelo menos suas lideranças: eram mulheres com ligações pessoais com os diretores de jornais, que compartilhavam não apenas o mesmo meio social e material como também o mesmo universo simbólico - as posições políticas e sociais fortemente conservadores e elitistas e, sobretudo, o forte sentimento anticomunista. Havia nessa relação "pessoal", portanto, uma identidade de cultura política. (CORDEIRO, 2009, p.51)
\end{abstract}

\title{
4. Mulheres da resistência: dupla transgressão
}

Ao mesmo tempo, a oposição à ditadura brasileira é comumente retratada de maneira estável e homogênea como a união de estudantes, artistas e operários. Assim, são invisibilizadas tanto as particularidades pessoais como de lutas setorizadas dentro do movimento maior. O objetivo comum contra a ditadura parece amenizar todos os possíveis confrontos internos, como explicita Míriam Leitão: 
A resistência é, por sua natureza, anárquica, desorganizada, fragmentada. [...] Os opositores divergiam sobre a melhor estratégia, escolheram táticas distintas, brigaram, se uniram e se protegeram. Não há unanimidade numa resistência. Os métodos são diversos e contraditórios, mas, mesmo sem saber, estão todos remando o barco na mesma direção e integrando o mesmo movimento que vai, aos poucos, minando a força autoritária. (LEITÃO em MAGALHÃES, 2013, p.21-22)

No livro Mulheres, ditaduras e memórias, Susel Oliveira da Rosa explora como mulheres militantes da oposição eram duplamente transgressoras, por serem agentes políticos contra a ditadura, mas também por romperem padrões de gênero. Ao se atentar para os recortes dentro da oposição, percebe-se que a revolução socialista ou comunista era uma revolução feita por homens, mesmo tendo a participação das mulheres, como auxiliares (ROSA, 2013, p.40).

O romance Subterrâneos da liberdade I, de Jorge Amado, é protagonizado pelo casal de jovens militantes João e Mariana. Ele, um dos dirigentes do Partido Comunista. Ela, auxiliar que dava recados e oferecia café. No momento em que ela se apaixona por João, o autor atribui a ela desejos de se tornar a esposa ideal: "dura é a vida dos camaradas (...) que são solteiros e não têm quem cuide de sua comida, de sua roupa, não têm um seio onde repousar a cabeça fatigada" (AMADO, 1980, p.95). Publicado originalmente em 1954, o romance retrata um modelo de revolução ainda reproduzido décadas depois. A figura universal do militante era política e masculina. Eram todos soldados. Os discursos procuravam anular as diferenças em prol da unidade da revolução. "O marxismo não alterou a ordem misógina do mundo, muito pelo contrário, o feminismo continuou relegado pela esquerda" (ROSA, 2013, p.38). Apenas elas precisavam passar por transformações: entrar no movimento significava apagar o ser mulher para tornar-se o ser militante. Clandestinidade é, por essência, invisibilidade. As mulheres precisavam se dessexualizar, na postura e no visual, a fim de serem militantes discretas (ROSA, 2013, p.45-46). Assim, sequer o invisível era igualitário.

O resultado da dupla atuação era também uma dupla acusação. As presas políticas eram vistas pelos militares como mais do que terroristas. Eram terroristas mulheres dentro da ameaça comunista, também tida como masculina. Enquanto para a direita a maternidade era um símbolo apolítico, na oposição a figura da mãe era substituída pela da bruxa e da prostituta nas mãos dos torturadores, sempre homens (ROSA, 2013, p.59). 
A presunção equivocada de que a conciliação é uma tarefa fácil para a esquerda oculta as opressões, mas também a percepção da beleza de seres tão singulares criarem fortes laços por uma experiência comum. Esta ideia, sob a ótica de gênero na oposição, é retratada no documentário Torre das donzelas. O longa-metragem recupera, 40 anos depois, vivências de um grupo de as jovens revolucionárias presas na ala feminina do Presídio Tiradentes, em São Paulo, entre as quais Dilma Rousseff. Em primeira pessoa, elas contam as dificuldades e pequenas alegrias do período em que ficaram encarceradas. A principal mensagem do documentário é a forte conexão construída entre as presas políticas. As "donzelas" - que zombam do título - tornaram-se uma família com tamanha intimidade e carinho que em alguns depoimentos, inclusive o de Dilma, contam que o momento da soltura foi marcado por certa tristeza e insegurança, já que significava abandonar aquela comunidade e talvez nunca ver as irmãs novamente.

Entretanto, antes de se consolidarem como um grupo, estas eram mulheres de diferentes classes sociais, idades e formações. Os desafios causados por fatores externos já são esperados - como medo, riscos à saúde e saudades da família -, mas a convivência intensiva também resultava em faíscas entre elas, apesar da concordância comum da defesa da democracia. Umas acreditavam que, como revolucionárias, deveriam engolir o choro. Outras cediam o colo. Parte do grupo organizou uma rotina para prática de exercícios físicos. Outra parcela resistiu, porque era contra qualquer tipo de ordem. A Torre das Donzelas é um microcosmo do feminino na esquerda. O livro Mulheres, ditaduras e memórias, por sua vez, foi resultado de pesquisas sobre três opositoras da ditadura militar. A autora observa que as personagens em questão não se conheceram, não foram amigas, mas, por terem vivido os mesmos tempos sombrios, automaticamente compartilham uma "inquietação e compromisso com o mundo" (ROSA, 2013, p.19).

A partir dessas questões, serão analisados os discursos de Míriam Leitão sobre sua vivência como jornalista e ex-presa política do regime. A proposta jamais é a de isolar este caso como especial ou mais relevante que outras histórias, mas, tomá-lo, assim como em Torre das Donzelas, como uma representação da interseção que motivou esta pesquisa: jornalismo, oposição à ditadura e feminismo. 


\section{Míriam Leitão - uma jovem revolucionária e feminista}

Nascida em Caratinga, pequena cidade no interior de Minas Gerais, em 1953, Míriam de Almeida Leitão Netto, em uma família de 11 irmãos, era considerada a filha rebelde que com 10 anos contestava a divisão de tarefas dentro de casa. Ao ler Simone de Beauvoir aos 16, deu nome ao sentimento e se afirma feminista desde então ${ }^{2}$. Ao lembrar histórias da infância para o documentário Parte da conversa, o irmão Cláudio Leitão conta que "Mirinha era uma pessoa de discursos" (LEITÃO para PARTE, 2019). Desde pequena, ela queria ter opinião, poder concordar ou discordar do que diziam. Para se inteirar dos acontecimentos, lia diariamente o jornal com o pai e o esperava terminar para que pudesse devorar os cadernos de política e economia. Foi a partir da leitura que desenvolveu pensamento crítico sobre situações do país e da sociedade e, em um caminho natural, entrou em contato com a militância de forma pontual e sutil, com o Grupo Caratinga (LEITÃO, 2017a, p.34). Entre Guimarães Rosa e Machado de Assis, conseguiu ter acesso ao Manifesto Comunista e ao 18 Brumário (ABREU e ROCHA, 2006, p.83).

Em 1970, mudou-se para o Espírito Santo para iniciar a graduação e, como qualquer adolescente de 17 anos, tinha dúvida de qual curso escolher. "Hoje eu olho pra trás e vejo que na verdade era uma dúvida tola, porque obviamente era jornalismo". Como a Universidade Federal do Espírito Santo não oferecia o curso de Comunicação ainda, ela considerou História uma boa opção. Sozinha e com a vontade de ser independente, logo comprou o jornal $A$ Tribuna para procurar qualquer emprego que a ajudasse a se manter. A primeira vaga que encontrou foi a de repórter do próprio jornal, em que a única exigência era ter o segundo grau completo e saber datilografar. Fez o teste e passou. "Quando eu entrei, eu precisei de 24 horas. Só. Pra saber que era aquilo que eu queria fazer para o resto da minha vida. Que ali era o lugar mais perto da conversa. No jornalismo era onde você sabia das coisas" (LEITÃO para PARTE, 2019).

Nesta época se filiou ao clandestino Partido Comunista do Brasil. Ao receber o codinome de Amélia, a jovem revolucionária quis reagir, por não ter qualquer identificação com o estereótipo ${ }^{3}$ que carrega o nome, mas não quis discordar do dirigente na primeira reunião. Míriam tinha funções mais simples, como distribuir folhetos ideológicos e pichar muros com frases de efeito (LEITÃO, 2017a, p.108).

\footnotetext{
${ }^{2}$ Esta informação, como todas as outras que serão citadas sem indicação de referência, foram obtidas em entrevista de Míriam Leitão cedida à autora em 2/9/2919, no Rio de Janeiro.

${ }_{3}^{3}$ Amélia tornou-se referência machista de exemplo de mulher que segue os moldes esperados pelo patriarcado após a música popular brasileira de mesmo nome, de Ataulfo Alves e Mário Lago.
} 
Eu não fiz atos, eu fiz mais uma atitude. Até inocente, porque não tinha muito efeito prático. Pichar um muro, espalhar um panfleto ou pregar um cartaz pequenininho nos orelhões era só uma coisa pra dizer: estamos vivos. Não tá todo mundo concordando.

Lá conheceu o estudante de Medicina Marcelo Netto, que fazia parte do diretório nacional do PCdoB e se tornou namorado e parceiro de luta. O casal "namorado com destaque no movimento e namorada com funções secundárias" se repete. Ao ser perguntada sobre a presença do machismo nos movimentos opositores, Míriam afirmou que a opressão existia em todas as esferas da sociedade, inclusive na esquerda. Afirma ter incomodado por sua atitude desafiadora: "Eu tive conversas muito difíceis com o chefe da organização [Foedes Santos] porque ele achava que eu era independente demais, que eu pensava demais com a minha própria cabeça".

A jornalista vivenciou o processo de invisibilização na oposição. Ela explica que, naquela época, a esquerda pensava que os recortes da opressão de gênero e raça, por exemplo, eram problemas considerados menores diante os objetivos principais, que eram a luta do proletariado e o fim da ditadura: "Não existia o conceito 'mimimi', mas era mais ou menos isso. A questão racial não era tocada, a questão da mulher não era tocada. Era a ideia de que você tinha que primeiro fazer a grande batalha, e que essas eram batalhas menores".

Míriam e Marcelo foram presos juntos, na frente da casa em que moravam em Vitória, no dia 3 de dezembro de 1972 (LEITÃO, 2017a, p.24) graças à delação de Foedes Santos, responsável pela queda do núcleo do partido no Espírito Santo (LEITÃO, 2017a, p. 134). Por seu maior destaque na militância, o então estudante de medicina ficou preso por 10 meses, sendo nove deles em uma solitária conhecida como "geladeira", sem direito à luz do sol e entretenimento, no maior aquartelamento da América Latina, no Rio de Janeiro (LEITÃO, 2017a, p.24-26).

Dentro do camburão, a estudante de 19 anos acreditava que havia sido presa apenas por estar acompanhando Marcelo, e ele seria o principal alvo. Ao chegar à prisão, foi recebida pelos militares aos gritos de "Amélia que era mulher de verdade!" e "Terrorista!", palavra usada para incitar a fúria dos pastores alemães treinados (LEITÃo, 2017a, p.86). "Só então percebi que minha prisão não era um engano" (LEITÃO a CUNHA, 2014). Míriam ficou presa por dois meses no $38^{\circ}$ Batalhão de Infantaria do Espírito Santo e sozinha nas três primeiras semanas, em uma cela sem janelas (LEITÃO, 2017a, p. 112). 
Com a menstruação atrasada, Míriam planejava comprar um teste de gravidez na segunda-feira, mas a prisão no domingo a impediu. Mesmo sem o resultado, ela tinha certeza de que carregava o primeiro filho e fez questão de informar o chefe do setor de inteligência do batalhão, capitão Guilherme, antes mesmo de ter a oportunidade de contar para Marcelo (LEITÃO, 2017a, p.174). "Ignoraram a revelação e minha condição de grávida não aliviou minha condição lá dentro" (LEITÃO para CUNHA, 2014).

O capitão, que "era um homem de não esquecer" (LEITÃo, 2017a, p.171), e o Dr. Pablo - posteriormente identificado como coronel Paulo Manhães -, conhecido por usar animais em suas sessões, foram os principais responsáveis pelas torturas da estudante. Antônio Waneir Pinheiro Lima, apelidado de Camarão, era um sargento da equipe de Manhães e também participou de algumas sessões (LEITÃo, 2017a, p.382).

Capitão Guilherme coordenava todas as sessões de interrogatório e tortura no seu batalhão. Enquanto os outros militares cobriam seus nomes na farda com fitas adesivas, ele fazia questão de não esconder sua identificação (LEITÃo, 2017a, p.179). O capitão torturava fisicamente como todos os outros, mas seu forte era ameaçar tanto os prisioneiros como seus familiares, com o objetivo de desestruturá-los psicologicamente. Ao chegar ao batalhão, Míriam assumiu a postura de intimidá-lo de volta:

\begin{abstract}
Míriam estava parada em pé, perto da porta da cela, onde a haviam mandado ficar. Ele passou e lançou aquele olhar frontal. Ela sustentou o olhar. O militar voltou e a encarou. Como a minha mãe devolveu a encarada, a batida veio forte, com a mão espalmada. "Nunca mais olhe para mim desse jeito", gritou. Ela permaneceu em silêncio, mas continuou olhando (LEITÃO, 2017a, p.181).
\end{abstract}

As agressões ordenadas por capitão Guilherme eram rotineiras, e muitas vezes a estudante era obrigada a ficar nua em meio aos torturadores, todos homens. Um dos episódios mais marcantes na passagem de Míriam na prisão foi quando foi colocada, nua, em uma sala escura com a jiboia de Dr. Pablo, onde ficou por horas. Outro episódio foi o que, segundo Míriam, mudou algo dentro dela. Em uma noite de interrogatório com Camarão, Dr. Pablo e outro fardado não identificado, a então estudante sofreu assédio sexual e ameaças de estupro. A mandaram tirar a roupa. Comentaram sobre sua aparência. A apalparam, bolinaram. Um dos homens a obrigou a deitar com ele no sofá. "Não chegaram a consumar nada, mas estavam no limite do estupro" (LEITÃO, 
2014)4. Apesar e caso com a jiboia ser o mais conhecido, foi o segundo episódio que levou Míriam ao extremo, e pela primeira vez, a deixou com vontade de matar os torturadores a sangue quente - segundo ela, uma arma não bastaria. Após aquela noite, ela não se sentia mais uma menina (LEITÃO, 2017a, p.401).

Um dia, um outro militar, que não era nenhum daqueles três [capitão Guilherme, Dr. Pablo e um não identificado], botou um revólver na minha cabeça e falou: "Eu posso te matar". E forçou aquele cano frio na minha testa. Me deu um sentimento enorme de solidão, de abandono. Eu me senti absolutamente só no mundo. Pela falta de notícias, imaginava que o Marcelo estava morto. Entendi que iria morrer também e que ninguém saberia da minha morte, pensei. Mas não quis demonstrar medo. Lembro que o homem do revólver tinha olhos azuis. Olhei nos seus olhos e respondi: "Sim, você pode pode me matar". E repeti, falando ainda mais alto, com ar de desafio: "Sim, você pode!" (LEITÃo para CUNHA, 2014).

A identidade de Dr. Pablo, conhecido como um dos mais violentos oficiais do DOI-Codi, na Tijuca, Zona Norte do Rio, foi revelada em reportagem de Chico Otavio, Juliana Dal Piva e Marcelo Remígio para O Globo em 2012. Na entrevista, que durou cinco horas, o coronel confessou o uso de cinco jacarés e uma jiboia de seis metros nas torturas. Os animais foram capturados à beira de um rio no sul do Pará, quando Manhães participou da repressão à Guerrilha do Araguai. Apelidou os jacarés de Pata, Peta, Pita, Pota e Joãozinho. A cobra, de Míriam (OTAVIO, PIVA e REMÍGIO, 2012). A reportagem de $O$ Globo que revelou a identidade de Dr. Pablo cita três vítimas das torturas com animais. Ao ler a matéria, Míriam Leitão teve uma crise de choro. Mas naquele momento não revelou aos colegas de trabalho, tampouco aos filhos, que seguiram a mesma profissão, que aquele também havia sido seu torturador (LEITÃO, 2017a, p.69).

A única vez que Míriam havia relatado as torturas publicamente foi em 1973, diante do Tribunal Militar, quando foi processada com base na Lei de Segurança Nacional. Uma transcrição parcial do auto de qualificação e do interrogatório estão entre depoimentos reunidos pelo projeto "Brasil: Nunca Mais". Nele consta o anúncio da gravidez, a falta de alimentação, a nudez, a tortura com a cobra e o esclarecimento: "a interrogada quer declarar perante o Conselho que, na verdade, subscreveu o Termo de Declarações mas exclusivamente porque temeu pela sorte de seu filho" (ARNS, 1996. Tomo V, Volume 3, p. 239).

\footnotetext{
${ }^{4}$ Até 2009 , a lei penal brasileira considerava como estupro a conjunção carnal violenta. A Lei no 12.015/09 também passou a considerar estupro qualquer prática libidinosa sem consentimento.
} 
Presa, Míriam prometeu a si mesma que jamais choraria na frente dos militares, nem mesmo quando recebia visitas de familiares. E cumpriu. Quando libertada, em fevereiro de 1973, a estudante de 19 anos estava com 39 quilos, anêmica e grávida de cinco meses sem barriga aparente, com o diagnóstico de que o filho teria, no mínimo, muitas complicações (LEITÃO, 2017a, p. 175-186). Pediu Marcelo, ainda preso, em casamento, e oficializaram em ato burocrático em 2 de março de 1973 (p. 249). Filha de um pastor, Míriam recusou a cerimônia religiosa, porque "jamais aceitaria ser submissa" (p. 250). Também fez questão de manter o nome de solteira, porque adotar o sobrenome do marido iria contra seus ideais feministas. Meses depois, o bebê nasceu, perfeito. "Vladimir, foram tão difíceis os seus primeiros meses em mim, mas quando vi você, nascidinho e bem, eu pensei: venci a guerra" (LEITÃo em ABRAJI, 2019).

Mas apenas em 2014 este capítulo da história de Míriam Leitão tornou-se amplamente exposto, com sua entrevista ao jornalista Luiz Cláudio Cunha para o site Observatório da Imprensa. Ela explica que manteve o silêncio por três décadas por acreditar que a busca constante por um acerto de contas com o passado impede a construção do futuro. Mas após as Forças Armadas negarem a ocorrência de "desvios de função" em relatórios para a Comissão Nacional da Verdade, decidiu falar:

Guardo aqui a sensação de que a minha dor eu mesmo curo. Não é dela que se trata. O que é importante é a dor do país e ela faz certas exigências às instituições. Uma delas é esse reconhecimento das Forças Armadas de que erraram. [...] Nunca pedi indenização, nem Marcelo. Gostaria de ouvir um pedido de desculpas, porque isso me daria confiança de que meus netos não viverão o que eu vivi. É preciso reconhecer o erro para não repeti-lo. As Forças Armadas nunca reconheceram o que fizeram. Não cultivo nenhum ódio. Não sinto nada disso. Mas esse gesto me daria segurança no futuro democrático do país. (LEITÃ̃O a CUNHA, 2014)

\section{A trajetória da jornalista}

No início de sua carreira, se deparou com redações de poucas mulheres para se inspirar. Como muitas, Míriam vivia uma tripla jornada: de militante, estudante e jornalista. $\mathrm{Na}$ tentativa de fazer oposição por meio do jornalismo, ela conta que tentava imprimir um olhar mais humano sobre os acontecimentos do dia a dia. "Se eu ia cobrir um despejo em uma favela, por exemplo, eu tentava colocar no texto um pouco do sentimento de empatia com os moradores, e não com a polícia". Aos 19 anos, se deparou com a primeira atuação direta da ditadura em seu caminho profissional, com sua primeira 
matéria censurada, ao cobrir uma das greves que Marcelo chefiava no primeiro veículo em que trabalhou (LEITÃO, 2017a, p.108).

Ainda muito abalada quando saiu da prisão, Míriam conseguiu voltar a trabalhar na Rádio Espírito Santo graças ao acolhimento de Euzi de Moraes, diretora da fundação a que o veículo pertencia, que a designou para fazer apenas trabalho interno, de forma que não precisasse se expor na rua. Mesmo na suposta abertura política do governo Médici, o governador do Espírito Santo, Élcio Alves, começou a dizer que demitiria todos os repórteres de esquerda da rádio. Antes que a medida a atingisse, voltou para $A$ Tribuna como editora internacional, para em um ano ter sua demissão exigida pelo governador.

No fim de 1975, foi para A Gazeta ser editora de economia. Logo foi demitida porque, segundo o editor-chefe, não tinha noção de hierarquia. Ao contar do episódio em entrevista para o livro Elas ocuparam as redações, Míriam afirmou que sempre foi atrevida, o que causava transtornos no início da carreira. Em 1977, esperando o seu segundo filho, Matheus, mudou-se para Brasília para cursar Jornalismo na UnB, por causa da obrigatoriedade do diploma (LEITÃO para ABREU e ROCHA, 2006, p.81-84).

Grávida, enquadrada na Lei de Segurança Nacional e ainda graduanda, conseguiu o emprego que considera o mais importante da sua vida, na Gazeta Mercantil. Sidnei Basile a contratou para cobrir o Itamaraty: "Era a melhor vaga. Era como se a ditadura já tivesse acabado" (LEITÃO para PARTE, 2019). Lá trabalhou por seis anos, até decidir que precisava conhecer melhor o Brasil, já que acreditava que a ditadura estava perto do fim, e foi para O Globo cobrir política (LEITÃO para ABREU e ROCHA, 2006, p.85).

Mudou-se para São Paulo no fim de 1982 para ser editora-assistente da revista Veja, onde teve experiência que julga negativa. Segundo Míriam, "tudo era muito centralizado, escrevia-se o que os chefes queriam que fosse escrito. [...] Era um total centralismo, da opinião e da maneira de escrever" (LEITÃO para ABREU e ROCHA, 2006, p.91). Ao ser demitida, ouviu que não sabia escrever. Naquele momento, se sentiu desprovida do que a tinha levado ao jornalismo. "Eu achava que era a ferramenta que eu tinha, sabe? Quando você sabe: eu vou pra luta com essa arma. Aí te dizem: você não tem essa arma". A demissão na Veja foi um episódio difícil em sua carreira, mas não mais alarmante do que a vez que foi demitida por assédio, ao recusar relações sexuais com um chefe (LEITÃo para PARTE, 2019). A jornalista não revela em qual veículo. 
Míriam conta que não sofreu assédio de superiores enquanto era foca, e sim quando já estava há anos no jornalismo eixo Rio-São Paulo. Naquela época, o ambiente de trabalho ainda era um espaço em que ouviam-se comentários machistas em silêncio, e denúncias de assédio bem-sucedidas eram inimagináveis. Míriam descreve o machismo como uma doença social com a qual é preciso lutar a vida inteira. A jornalista se classifica como "feminista de antigamente". Ao comparar aquela época com a atual, afirma: "A minha alegria hoje é saber que eu atravessei o deserto. O que eu chamo de deserto é o momento em que as mulheres pararam de falar sobre esse assunto como se fosse feio".

No fim de 1985, no Rio de Janeiro, aceitou cobrir férias do colunista social Zózimo Barrosos do Amaral no Jornal do Brasil. O período em que escreveu sobre a elite carioca tornou-se uma memória cômica, porque não tinha familiaridade com esse universo, mas sabia bastidores do governo. Logo depois, tornou-se a primeira mulher editora de economia, "assunto que nos anos 60 era exclusivo para jornalistas homens" (LEITÃO em ABREU e ROCHA, 2006, p.11). Saiu do JB em 1990, passou um ano assinando uma coluna de economia do Estado de S. Paulo e em 1991 foi para O Globo, onde está até hoje. Míriam ganhou em 2005 o Prêmio Maria Moors Cabot, o mais tradicional prêmio internacional de jornalismo, concedido desde 1939. Dos 32 brasileiros já premiados, as únicas mulheres são Míriam e Sylvia Bittencourt, a Majoy, correspondente da United Press na Europa na Segunda Guerra Mundial.

Ao se lembrar da jovem Míriam, a jornalista não se imagina com uma postura diferente: "Eu nunca me arrependi do que eu fiz. Eu acho que não fiz grandes coisas, mas um governo autoritário acaba quando muita gente faz um pedacinho, então eu acho que fiz meu pedaço". A jornalista justifica que a filiação a partidos clandestinos era então a única opção para quem queria fazer sua parte, no momento em que o AI-5 havia acabado com o movimento estudantil e a mobilização nas ruas. E diz que faria tudo de novo.

A direita me julga como se eu tivesse feito uma coisa criminosa porque eu estava me opondo ao regime. E uma coisa que é da conquista da humanidade é o direito de se rebelar contra um regime injusto e ditatorial. Se ninguém tivesse lutado pela democracia, como nós estaríamos hoje? A luta do espírito humano é por mais liberdade e por avanços. Quando a pessoa acha que o que eu fiz é condenável é porque ela gosta da ditadura. Então se eu faria tudo de novo? Faria, porque naquele contexto era o que se podia fazer. E eu precisava fazer algo. Eu não ia ficar em silêncio. 
Míriam não se vinculou a outras organizações políticas e hoje se considera de centroesquerda. Optou por seguir carreira como colunista para fugir da hierarquia machista imposta nos jornais, que impede mulheres de chegarem a cargos de chefia (LEITÃO em ABREU e ROCHA, 2006, p.104). Em suas colunas, ao tratar da economia para além dos números, aborda pautas feministas, mas também antirracistas e socioambientais. Ao sobreviver ao regime ditatorial como opositora, opinar na democracia deveria ser uma tarefa mais fácil. A jornalista comenta:

Quando começou a redemocratização, a ideia era que as pessoas pudessem divergir. Antes a gente tinha que ter o mesmo pensamento contra o regime, então agora a ideia é cada um livre pra pensar o que quiser. Então se eu pudesse ver naquele tempo o que eu vivi depois, eu tomaria até um susto.

Os dois mais notórios presidentes do país, o ex-líder sindicalista Luiz Inácio Lula da Silva (PT) e o ex-capitão de ultradireita Jair Bolsonaro (PSL), são seus críticos ferrenhos. A jornalista difere os ataques e afirma que os de Bolsonaro e seus apoiadores são mais sérios, porque "a ditadura acabou e agora é a construção do futuro, mas ele está prisioneiro lá, então ele sempre me viu como inimiga sem eu nunca ter escrito uma linha sobre ele antes. Ali, é o ódio gratuito".

Os ataques de Bolsonaro iniciaram-se antes mesmo de o nome de o representante da extrema direita ser mencionado nos textos e falas de Míriam. Em 2015, durante o processo de apuração do livro Em Nome dos pais, Matheus Leitão entrevistou o então deputado em seu gabinete em Brasília. Mesmo que o projeto da presidência ainda fosse um sussurro na época, Bolsonaro já era uma figura notória por defender abertamente a ditadura militar. O jornalista questiona o deputado: "Minha mãe foi colocada com uma jiboia numa sala do Exército brasileiro. E o senhor disse a seguinte frase: 'coitada da cobra'. O senhor reitera isso?". Bolsonaro respondeu "Reitero". O trecho do vídeo foi compartilhado por assessores do deputado entre seus apoiadores.

Na coluna "O ódio a bordo", de 2017, Míriam relata os ataques verbais que sofreu de petistas durante um voo. Entre os xingamentos que recebeu em silêncio, destacou a ironia de novamente ter sido chamada de "terrorista" por homens e mulheres de cerca de 50 anos em plena democracia. A Polícia Federal recomendou que a jornalista deixasse seu assento para viajar na parte da frente da aeronave. Míriam se recusou: "Diga à Polícia Federal que enfrentei a ditadura. Não tenho medo. De nada" (LEITÃo, 2017b). 
Quando passou a ter o nome diretamente citado nas colunas de Míriam, Bolsonaro não apenas reafirmou o embate como fez dela um alvo constante. Na coluna publicada em 14/11/2017, a jornalista critica o então deputado já com olhos na presidência pela falta de conhecimento econômico (LEITÃO, 2017). Horas após a publicação, Bolsonaro respondeu via Twitter: "Miriam Leitão, a marxista de ontem, continua a mesma. Se eu chegar lá vai querer lamber minhas botas, como fez com todos que chegaram ao Poder. Seu lugar é no chiqueiro da História" (BOLSONARO, 2017).

Em julho de 2019, a presença de Míriam precisou ser cancelada em um tradicional evento literário em Santa Catarina devido a ameaças de apoiadores de Bolsonaro. O coordenador do evento afirmou que a decisão foi tomada"com vergonha", prezando a segurança da convidada, e que foi a única vez que algo do tipo aconteceu em 12 anos de evento (AGUIAR, 2019).

Assim como respondeu ao ser perguntada se faria algo diferente em sua época militante, Míriam afirma que não faria nada diferente em sua carreira profissional. Entende que se o jornalista incomoda a lados opostos, é porque seu trabalho é correto. Ela afirmou ter elogiado e criticado medidas dos governos do PT como alguém que pensa sobre cada decisão, e não assume uma postura maniqueísta de apoiar ou se opor integralmente. "Eu incomodo porque eu não faço uma coisa que é só verborrágica. Eu prefiro entrar no debate qualificando, explicando, trazendo os dados, a informação".

Míriam foi homenageada no $14^{\circ}$ Congresso Abraji de 2019 com as palavras: "Ao cobrir economia, ela nos lembra que valores são também princípios, e que valor é também coragem". Em seu discurso, afirmou que seu coração bate pelo jornalismo, pelo meio ambiente, por um país com menos desigualdade e que inclua os negros. Enfatizou que seu coração bate pela inclusão das mulheres, que segundo ela, é a sua briga mais antiga. E, por fim, que seu coração bate pela democracia (LEITÃo em ABRAJI, 2019).

Míriam acredita que ter começado a vida profissional e adulta em tamanha tensão a fez ser mais resistente e capaz de ter um pensamento estratégico. A trajetória profissional marcada por demissões desafiou a jornalista. A estratégia foi diversificar formatos e dominar diferentes técnicas do jornalismo, em uma época em que pouco se transitava por meios de comunicação distintos:

As pessoas falam: "Você muito precocemente ficou multimídia". Aí eu falo: não era porque eu estava com a visão de que o mundo caminharia tecnologicamente pra isso, mas porque eu queria permanecer na profissão. Então, se existe uma coisa que talvez 
tenha se desenvolvido seja a capacidade de lutar para permanecer. Não querem que eu fique, mas eu vou ficar.

O livro Elas ocuparam as redações traz a percepção de que, mesmo quando as jornalistas mulheres são engajadas, a agenda feminista não afeta a cobertura jornalística (ABREU e ROCHA, 2006, p.12).

No $14^{\circ}$ Congresso Abraji de 2019, Míriam Leitão respondeu, ao ser perguntada sobre um possível incômodo ao entrevistar militares que defendem a ditadura, que é preciso fazer um bloqueio e separar a jornalista da ex-torturada. Tal postura pode ser observada no episódio que a levou a compartilhar suas memórias. Após a divulgação dos relatórios das Forças Armadas à Comissão Nacional da Verdade negando torturas durante a ditadura, a jornalista entrevistou o então ministro da Defesa, Celso Amorim. O episódio ganhou destaque no Observatório na Imprensa com a reportagem A repórter pergunta, o ministro gagueja, de Luiz Cláudio Cunha:

Míriam fez o que o resto da grande imprensa, acomodada e preguiçosa, não fez [...]. Com a elegância exigida, Míriam preservou os limites institucionais de sua entrevista com o ministro da Defesa, sem jamais confundir sua história de vida com a vida do país, embora elas se cruzem e se confundam (CUNHA, 2014).

Mesmo que Míriam Leitão consiga separar estas duas facetas, fica claro nas entrevistas de Em nome dos pais que a vivência da jornalista como ex-torturada tem impacto em terceiros, inclusive no outro lado da história. Em 2008, Matheus Leitão entrevistou o coronel Carlos Alberto Brilhante Ustra na tentativa de conseguir respostas que os militares protegem há décadas. Ustra negou participação em torturas. Após a publicação da reportagem, a mulher de Ustra, Joseita, publicou uma crítica ao jornalista no site da Ternuma (acrônimo para Terrorismo Nunca Mais), organização fundada em 1998 por militares, ex-militares, familiares e simpatizantes para enaltecer a 'revolução de $1964^{\prime}$.

O site recebe os visitantes com um banner animado que diz "Ontem, hoje e sempre. Salve 31 de março! Bem-vindo! Aqui você conhecerá a história das ações terroristas praticadas por maus brasileiros" (TERNUMA, [200-]). Míriam, Marcelo e consequentemente Matheus encaixavam-se como maus brasileiros, e Joseita defendeu o marido das acusações. Mas a mulher de Ustra só o fez depois de uma ligação para Matheus: "Ao telefone ela disse que, embora a linha da reportagem a desagradasse bastante, ela entendia minha posição, e soluçou ao dizer que sentia muito pelo que fizeram com minha mãe, especialmente o episódio da cobra" (LEITÃO, 2017a, p.83). 
Na tentativa de entrevistar os três filhos de capitão Guilherme para o livro, Matheus conversou por telefone com a filha mais velha, Mônica. Apesar de se mostrar indisponível para tratar de qualquer assunto que envolvesse a participação de seu pai na ditadura, Mônica comentou sobre Míriam. Antes de encerrar o contato com Matheus, a filha do torturador o disse:

Acho que não estou preparada para isso porque é uma história que não considero minha, sei que é sua. Li algumas coisas da sua mãe também, fiquei muito sensibilizada. [...] Pra você deve ser muito difícil, pra ela mais ainda. Ela tirou forças não sei de onde, do fundo da alma dela, para se tornar a pessoa que é, importante, famosa, inteligente, o que ela já devia ser na época. Você tem que ter muito orgulho de ser filho dela, com certeza. (LEITÃO, 2017a, p.409-410)

Nem Joseita nem Mônica citaram Marcelo, apesar de Matheus ter deixado claro que sua pesquisa era sobre a história dos pais.

A edição do dia 6 de junho de 2017 do programa Conversa com Bial, do jornalista Pedro Bial, na Rede Globo, teve Matheus e Míriam Leitão e Clarice e Ivo Herzorg como entrevistados. Os parentes de Vladimir Herzog, jornalista assassinado pela ditadura que se tornou símbolo do movimento de oposição, abriram o programa. Quando chegou sua vez, as primeiras palavras de Míriam foram para manifestar a honra de dividir o sofá com os Herzorg, por todo o trabalho e importância de transformar uma vivência tão dolorosa em algo positivo para o país. E justificou seu silêncio:

Eu não falava, eu fui um pouco empurrada pelo Matheus. [...] Acho que minha história é tão pequena perto das histórias todas que aconteceram. [...] Eu achava que minha história não era importante e que eu precisava seguir a vida. Eu só falei em uma circunstância muito específica. (LEITÃo para BIAL, 2017)

A tentativa de lançar luz em lados menos expostos das camadas abordadas - como foi feito com a quebra da imagem heróica da imprensa, a exposição do machismo na esquerda e a contemplação da forte atuação feminina pró-golpe - também pode ser observada na escolha de Míriam Leitão como objeto deste trabalho.

A ampla visibilidade da jornalista levanta questionamentos interessantes sobre o silenciamento histórico. Mesmo para a mulher que desde criança sempre ousou falar o que pensa, que se tornou uma das mais respeitadas jornalistas do país, presente em poderosos meios de comunicação, as memórias dos porões da ditadura a mantiveram calada por décadas. 


\section{Considerações finais}

Durante a ditadura militar brasileira, o machismo era regra. Mas enquanto o tratamento diferenciado dado às presas políticas apenas por serem mulheres é mais evidentemente cruel e portanto, homogeneamente repudiado pela esquerda, as opressões dentro dos espaços que deveriam ser seguros - como os partidos clandestinos e as redações de jornais - são responsáveis pela manutenção do silêncio de vozes femininas, ao ter o apagamento como pré-requisito para participar da oposição organizada enquanto a história era feita, e ao cultivar uma hierarquia que dificulta o alcance de mulheres na chefia dos veículos de comunicação responsáveis por contar esta história.

Também é interessante observar que a invisibilidade de mulheres nas memórias deste período histórico não vem, em todos os casos, de terceiros. O silêncio de vozes femininas também é, em parte, das próprias. Em Direitas em movimento, Cordeiro (2009) se aprofunda sobre a dificuldade de mulheres tornarem públicas suas posições sobre a ditadura, olhando para o lado oposto do que se pesquisa aqui. Ao explorar a atuação das mulheres a favor do regime militar, a autora comenta a dificuldade de coletar depoimentos da direita. O motivo é o risco da incompreensão, "o medo de suas posturas passadas se terem tornado incompreensíveis no presente" (CORDEIRO, 2009, p 138). Segundo ela, as esquerdas venceram no campo da memória. A autora explica que a história que se conta sobre estes 21 anos faz parecer que a resistência representava a sociedade brasileira diante a ditadura e apaga a considerável parcela da população que apoiava o regime.

Míriam Leitão foi convidada para abrir o livro do projeto Resistir é preciso, idealizado pelo Instituto Vladimir Herzog. No texto $A$ difícil travessia, a jornalista começa compartilhando um sentimento de também possível não compreensão:

Quem viveu sabe, mas não consegue explicar. Os sobreviventes choram ao ouvir certas músicas, entendem-se quando se olham nos olhos, mas como passar adiante esse sentimento? Se as novas gerações não compreenderem a lógica daquele tempo, o país está correndo um perigo extremo. [...] Hoje, 50 anos depois do início da ditadura e quase três décadas de seu fim, ainda é preciso resistir. Só agora versões mentirosas são apagadas, só agora a certidão de Vladimir Herzog é reescrita, só agora se abrem armários dos arquivos oficiais para resgatar pedaços da verdade sonegada. (LEITÃO em MAGALHÃES, 2013, p.18-23)

Todo silêncio é prejudicial à construção da história. Analisa-se, porém, que por parte das mulheres pró-golpe há privilégio na decisão de não compartilhar tais memórias, 
enquanto para ex-presas políticas, o trauma adquirido no passado sempre acompanha o presente, assim como o medo de que ele se torne um possível futuro. "a resistência precisa se opor ao tempo" (LEITÃO em MAGALHÃES, 2013, p.23).

A última presidente da Camde, Eudoxia Ribeiro Dantas, rompeu o padrão ocultista da direita e escreveu um livro de memórias sobre a sua atuação pró-golpe, para, segundo ela, impedir o esquecimento da história e orientar seus descendentes (CORDEIRO, 2009, p.165-166). Do outro lado, temos Míriam Leitão, uma das jornalistas mais expostas do país, que não havia revelado os detalhes de sua vivência como ex-presa política nem para o filho torturado junto com ela, ainda no ventre.

O privilégio está na possibilidade de escolher o lugar do silêncio no presente - seja a permanência ou o rompimento. A impunidade garantida pela Lei da Anistia faz com que a ferida dos horrores da ditadura seja publicamente aberta. Assim, mesmo que os traumas das ex-presa tenham cicatrizado no âmbito pessoal, os absurdos da esfera pública impedem que o silêncio seja uma posição confortável - como aconteceu com Míriam, na decisão de finalmente conceder entrevista para o Observatório da Imprensa. Por fim, volto a enfatizar que a motivação por trás da escolha de Míriam Leitão como tema desta pesquisa não tem o objetivo de apontar sua história como única ou mais relevante entre as vividas por mulheres jornalistas opositoras da ditadura militar. Como seria impossível contemplar todas, Míriam foi selecionada para representar estas mulheres que, mesmo tão distintas, compartilham as dores de um passado tão presente. Agora, cabe a nós, da geração nascida na democracia, o compromisso de manter esta conexão viva.

\section{Referências}

ABREU, Alzira Alves de; ROCHA, Dora. Elas ocuparam as redações. Rio de Janeiro: FGV, 2006.

AGUIAR, Tiago. Feira do Livro em SC cancela participação de Miriam Leitão por 'questões de segurança'. O Globo, São Paulo. 16/07/2019. Disponível em: <oglobo.globo.com/brasil/feira-do-livro-em-sc-cancela-participacao-de-miriam-leitaopor-questoes-de-seguranca-23812482>. Acesso em: 20 out. 2019.

AMADO, Jorge. Subterrâneos da liberdade I: Os ásperos tempos. Rio de Janeiro: Record, 1980.

ARNS, Paulo Evaristo. Brasil, nunca mais. São Paulo: Vozes, 1996.

BOLSONARO, Jair. Miriam Leitão... 14 nov. 2017, 10:11 am. Twitter: @JairBolsonaro. 
Disponível em: <https://twitter.com/jairbolsonaro/status/930407781995249666>. Acesso em: 3 dez. 2019.

BRASIL. Lei n. 6.683, de 28 de agosto de 1979. Concede anistia e dá outras providências. Disponível em: <http://www.planalto.gov.br/ccivil 03/leis/l6683.htm>. Acesso em: 11 set. 2019.

CARVALHO, Aloysio Castelo de. A rede da democracia. Niterói: NitPress, 2010. CHAGAS, Carlos. A ditadura militar e os golpes dentro do golpe: 1964-1969: A história contada por jornais e jornalistas. Rio de Janeiro: Record, 2014. CHARLEAUX, João Paulo. Por que torturadores da ditadura não vão para a cadeia no Brasil. Nexo Jornal, 24/12/2015. Disponível em: <www.nexojornal.com.br/expresso/2015/12/24/Por-que-torturadores-da-ditaduran\%C3\%A30-v\%C3\%A3o-para-a-cadeia-no-Brasil>. Acesso em: 20 out. 2019. COELHO, Moacyr. Um acordo forçado: 0 consentimento da imprensa à censura no Brasil. [Entrevista cedida a] Anne-Marie Smith. Rio de Janeiro: FGV, 1997. CORDEIRO, Janaina M. Direitas em movimento. A Campanha da Mulher pela Democracia e a ditadura no Brasil. Editora FGV, 2009. CUNHA, Luiz Claudio. A repórter pergunta, o ministro gagueja. Observatório da Imprensa 19/08/2014. Disponível em: <observatoriodaimprensa.com.br/caderno-dacidadania/ ed812 a reporter pergunta o ministro gaqueja/>. Acesso em: 12 set. 2019.

KUCINSKI, Bernardo. Jornalistas e revolucionários: nos tempos da imprensa alternativa. São Paulo: Página Aberta, 1991.

KUSHNIR, Beatriz. Cães de guarda: jornalistas e censores, do AI-5 à

Constituição de 1988. São Paulo: Boitempo; Fapesp, 2004.

LEITÃO, Matheus. Em nome dos pais. $1^{\text {a }}$ ed. Rio de Janeiro: Intrínseca, 2017a. LEITÃO, Míriam. A difícil travessia. In: MAGALHÃES, Fabio. Resistir é preciso. São Paulo: Editora Instituto Vladimir Herzog, 2013.

LEITÃO, Míriam. Candidatos e mercado. O Globo. 14/11/2017c. Disponível em: <blogs.oglobo.globo.com/miriam-leitao/post/candidatos-e-mercado.html>. Acesso em: 9 dez. 2019.

LEITÃO, Míriam. Conversa com Bial. Entrevista concedida a Pedro Bial. Rede Globo, 06/06/2017. Disponível em <https://globoplay.globo.com/v/5922169/>. Acesso em: 6 set. 2019.

LEITÃO, Míriam. Em $14^{\circ}$ Congresso da Abraji, 2019, São Paulo. LEITÃO, Míriam. O ódio a bordo. O Globo. 13/07/2017b. Disponível em: <https://blogs.oglobo.globo.com/miriam-leitao/post/o-odio-bordo.html>. Acesso em: 
20 out. 2019.

LEITÃO, Míriam. Parte da conversa. [Entrevista cedida a] Outros Olhos Filmes. Rio de Janeiro: 2019.

MARCONI, Paolo. A censura política na imprensa brasileira (1968-1978). 2. ed. São Paulo: Global, 1980.

MONTES, Rócio. Chile destitui coronel por saudação a genocida da ditadura Pinochet em ato. EI País, Santiago. 16/10/2018. Disponível em:

<brasil.elpais.com/brasil/2018/10/16/internacional/1539658012_421100.html>. Acesso em: 1 dez. 2019.

NAPOLITANO, Marcos. 1964: História do Regime Militar Brasileiro. São Paulo: Contexto, 2014.

OTAVIO, Chico; PIVA, Juliana Dal; REMÍGIO, Marcelo. Relato dos porões: cobra e jacarés na hora da tortura. O Globo, Rio de Janeiro. 24/06/2012. Disponível em: <oglobo.globo.com/brasil/relato-dos-poroes-cobra-jacares-na-hora-da-tortura5305890>. Acesso em: 30 jul. 2019.

PERÍODos da Ditadura. Memórias da Ditadura. [S.I.] [200-]. Disponível em: <memoriasdaditadura.org.br/periodos-da-ditadura/> Acesso em: 3 mar. 19. ROSA, Susel Oliveira da. Mulheres, ditaduras e memórias: "Não imagine que precise ser triste para ser militante". São Paulo: Intermeios, 2013. TERNUMA. [200-] Disponível em: https://www.ternuma.com.br/. Acesso em: 26 jun. 2019.

TORRE das donzelas. Direção de Susanna Lira. Rio de Janeiro: 2018 (97 min.). VENTURA, Zuenir. Parte da Conversa. Rio de Janeiro: Outros Olhos Filmes, 2019. 